\title{
Pola Spasial Hak Tanggungan dalam Perkembangan Perkotaan Purwokerto
}

\author{
Nesty Vie Laily ${ }^{1}$ dan Iwan Rudiarto ${ }^{2}$ \\ Fakultas Teknik, Universitas Diponegoro, Semarang, Indonesia
}

Email Koresponden: nestyvie@gmail.com

Diterima: 2018-05-26 /Refisi: 2018-06-22 Disetujui: 2019-02-01

(2019 Fakultas Geografi UGM dan Ikatan Geograf Indonesia (IGI)

\begin{abstract}
Abstrak Hak tanggungan sebagai salah satu investasi swasta memiliki nilai besar, begitu juga di Perkotaan Purwokerto. Namun disatu sisi belum banyak yang melakukan analisis kontribusi terhadap perkembangan suatu wilayah khususnya perkotaan. Dengan mengidentifikasi pola spasial hak tanggungan menggunakan analisis Average Nearest Neighboor dan analisis densitas serta meng-overlay-kan hasil analisis pada struktur perkembangan Perkotaan Purwokerto diperoleh informasi pola perambatan kejadian hak tanggungan di dalam perkembangan Perkotaan Purwokerto. Hasil yang diperoleh bahwa ada kecenderungan pengelompokan kejadian hak tanggungan pada area peralihan/ berkembang (Edge) Perkotaan Purwokerto, dengan nilai rerata tetangga terdekat 0,572 pada tahun 2012 dan 0,625 pada tahun 2017. Untuk nilai tanggungan memiliki kecenderungan mengelompok di pusat kota (CBD). Hasil perhitungan kontribusi kejadian hak tanggungan (investasi) terhadap perubahan guna tanah di Perkotaan Purwokerto diperoleh nilai rerata sebesar 38,70\%, dengan kontribusi paling tinggi terletak pada wilayah Purwokerto Utara dan terkecil pada wilayah Purwokerto Timur.
\end{abstract}

Kata kunci: Tanah, Hak Tanggungan, Investasi, Perkembangan Perkotaan

\begin{abstract}
Mortgage as one of private investment has great value, the condition also in Purwokerto Urban Areas. Still few researchers, who do the analysis of mortgage contributions toward urban development. With identifying the spatial pattern of the mortgage, using Neighboor analysis and Almost average density analysis, the results of the analysis are overlayed in the structure of Purwokerto Urban Development. That will provide information on pattern of mortgage event distribution. The pattern of mortgage distribution tends to cluster in the transition zone / developing zone of urban Purwokerto. the result of Average Nearest Ratio Analyzing value 0.572 in 2012 and 0.625 in 2017. The spatial pattern value of mortgage tend to clustered in the Central Business District (CBD), with contribution of mortgage toward Purwokerto urban development, especially land use change obtained an average value 38,70\%. Area with the maksimum contribution is Purwokerto Utara and minimum contribution in Purwokerto Timur.
\end{abstract}

Keywords: Land, Mortgage, Investment, Urban Development

\section{PENDAHULUAN}

Tanah sebagai salah satu wujud dari ruang (dalam UU No 26 Tahun 2007 disebut sebagai ruang darat) memiliki jumlah tetap dan terbatas (Kivell, 1993) yang merupakan aset dan akses permodalan untuk menunjang aktivitas ekonomi (Syahyuti, 2011) dan perkembangan wilayah/kota yang identik dengan area tanah terbangun (Sadyohutomo, 2016). Perkotaan Purwokerto sebagai pusat kegiatan ekonomi (CBD) dan kawasan strategis (Pemerintah Kabupaten Banyumas, 2011), terindikasi banyaknya kejadian HT dan nilai tangungan (investasi privat) yang besar di ibukota Kabupaten Banyumas tersebut. Sejalan dengan pendapat Sutarno \& Kuncoro, (2003), investor cenderung memilih area perkotaan yang fasilitasnya lengkap dan tenaga kerja. Jumlah populasi penduduk yang meningkat dan terbatasnya ketersediaan tanah mengakibatkan tingginya permintaan akan tanah untuk digunakan (Whipple, 1995) sebagai pemukiman (Beckmann, 1969; J.-H. Kim, Li, Newman, Kil, \& Park, 2016; Udoka \& Kpataene, 2017) industri (Jiang, Ma,
Dingyang, Qinglei, \& Ruijuan, 2017) dan penggunaan lainnya, hal ini tentunya berimbas pada naiknya harga tanah (Nasucha, 1995; Beukes, 2000; Sadyohutomo, 2016), yang semakin mahal (Hermit, 2009). Pada sisi lain aktivitas manusia dalam ruang membutuhkan modal yang besar untuk kegiatan pembangunan. Hasil pembangunana ditandai dengan adanya pertumbuhan ekonomi (Adisasmita, 2013), yang akan memicu perkembangan wilayah/area (Kivell, 1993). Salah satu fungsi pertumbuhan ekonomi yang diungkap oleh Roy Harrod, (1963), dan Evesey Domar (1957), dalam penelitiannya terkait adanya modal dan investasi.

Dalam OECD (2011), investasi berdasarkan sumber dana dibedakan menjadi 2 (dua) pertama investasi publik (public investment), investasi yang dikeluarkan oleh pemerintah baik oleh Pemerintah Pusat/Pemerintah Daerah (Felice, 2016; Böventer, 1975; Peng, Song, \& Han, 2017; Dobrescu \& Dobre, 2014;Shi, Guo, \& Sun, 2017). Kedua investasi dari sektor swasta (private investment) baik dari masyarakat maupun koorporasi/badan hukum (Wang, Zhang, Wu, Zhou, \& 
Skitmore, 2017; Frick \& Rodríguez-Pose, 2018; Putri, Gunarto, \& Saimul, 2013). Investasi swasta sendiri (Chen, Wang, \& Singh, 2017) menjelaskan ada 2 (dua) sumber, pertama investasi dari luar negeri dan kedua investasi dalam negeri, dimana salah satu investasi dalam negeri diperoleh melalui utang dengan jaminan aset tanah (J. Kim \& Wang, 2018) yang di Indonesia diistilahkan Hak Tanggungan (hipotek/mortgage) sesuai UU Nomor 4 Tahun 1996 tentang Hak Tanggungan (Pemerintah Republik Indonesia, 1996).

Pada literatur lainnya dijelaskan bahwa ada korelasi antara jumlah/nilai hipotek terhadap pertumbuhan ekonomi suatu negara (Asabere, McGowan Jr., \& Lee, 2016) dan besarnya pinjaman hipotek berpengaruh signifikan pada pembangunan ekonomi (Nwamara \& Aronu, 2014; Aron \& Muellbauer, 2016), bahkan dalam tingkat yang lebih mikro dijelaskan pula nilai investasi privat/mortgage (dalam hal ini nilai tanggungan tinggi/besar) lebih banyak (mengelompok) di pusat pertumbuhan kota/CBD (Rae, 2015). Namun yang menjadi permasalahan adalah belum adanya penelitian yang mendiskusikan bagaimana investasi privat melalui HTmemilikiketerkaitan denganperkembanganwilayah/ area perkotaan. Hasil yang diharapkan dari penelitian ini adalah memberikan gambaran bagaimana investasi privat melalui HT/Hipotek memiliki keterkaitan dan kontribusi pada perkembangan perkotaan.

\section{DATA DAN METODE}

Penelitian ini menggunakan pendekatan deduktif dengan metode deskriptif kuantitatif. Pendekatan deduktif diharapkan dapat memberikan gambaran terkait sebaran dan pola hak tanggungan dalam koridor perkembangan Perkotaan Purwokerto. Metode kuantitatif untuk mendeskripsikan fenomena yang terjadi terkait dengan perkembangan kota dan pola kejadian HT/hipotek dan nilai tanggungan, dan bertujuan memberikan seberapa besar nilai atau kontribusi/keterkaitan sebaran dan pola HT/ hipotek dalam perkembangan Perkotaan Purwokerto.

Lokasi dalam penelitian ini adalah Perkotaan Purwokerto (eks. Kotif. Purwokerto) yang terdiri dari

Tabel 1.Kebutuhan Data
4 (empat) kecamatan yaitu Kecamatan Purwokerto Utara, Kecamatan Purwokerto Selatan, Kecamatan Purwokerto Timur, dan Kecamatan Purwokerto Barat. Perkotaan Purwokerto dipilih karena berdasarkan beberapa data sekunder dan informasi dalam 5 (lima) tahun terakhir mengalami transformasi baik struktur perekonomian dan struktur perkotaannya (spasial/ keruangan). Hal lain yang dijadikan pertimbangan

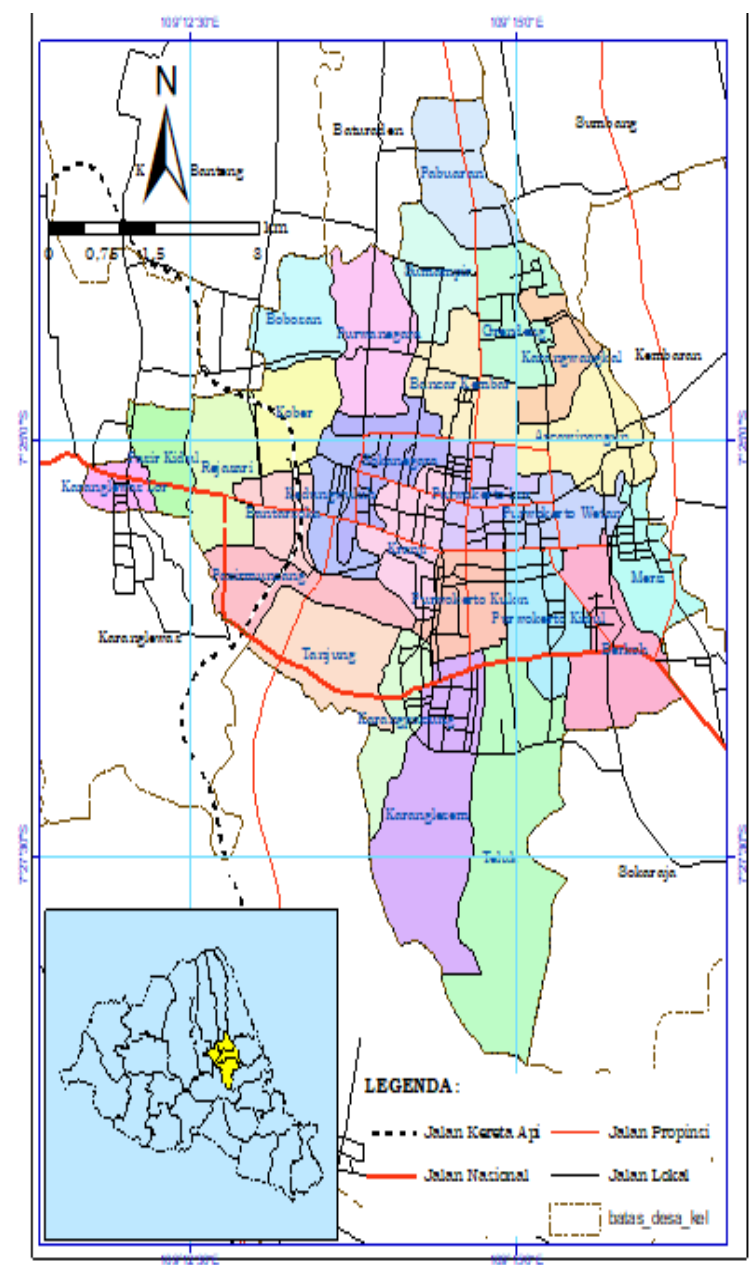

Sumber : Analisis 2018

Gambar 1. Lokasi Penelitian
DATA PRIMER

Lokasi pelayanan publik

Mengidentifikasi perkembangan Perkotaan Purwokerto

DATA SEKUNDER

\begin{tabular}{|c|c|c|}
\hline Data & Fungsi & Sumber Data \\
\hline Peta Pendaftaran Bidang Tanah & $\begin{array}{l}\text { Memetakan bidang tanah yang } \\
\text { diagunkan }\end{array}$ & BPN Kantah Kabupaten Banyumas \\
\hline Hak Tanggungan & $\begin{array}{l}\text { Memetakan sebaran HT di Perko- } \\
\text { taan Purwokerto }\end{array}$ & BPN Kantah Kabupaten Banyumas \\
\hline \multicolumn{3}{|l|}{ Peta RBI } \\
\hline Citra Satelit tahun 2012 \& 2017 & Untuk peta kerja & $\begin{array}{l}\text { BAPPEDALITBANG Kabupaten } \\
\text { Banyumas dan google map }\end{array}$ \\
\hline
\end{tabular}

Sumber : Analisis 2018

https://jurnal.ugm.ac.id/mgi|58 
dalam pemilihan Perkotaan Purwokerto, dimana jumlah kejadian HT yang terjadi di Perkotaan Purwokerto dibandingkan Kab. Banyumas sebagai wilayah induknya berkisar $>12.5 \%$ tiap tahunnya. Pemilihan lokasi juga dikarenakan Purwokero memiliki daya tarik seperti kota-kota besar di Jawa Tengah (Semarang, dan Surakarta) yaitu memiliki universitas negeri yang besar (Univ. Jend. Soedirman) serta sebagai pusat aktivitas perekonomian bagi wilayah sekitarnya (Banyumas, Purbalingga, Banjarnegara, Cilacap, dan Bumiayu).

Data penelitian ini berdasarkan perolehannya terdiri dari 2 (dua) jenis data pertama data primer berupa data lokasi koordinat tempat-tempat penting beserta atributnya dan kedua data sekunder yang diperoleh dari beberapa instansi seperti peta bidang, data hak tanggungan (dari BPN), peta topografi, peta guna tanah (dari BAPPEDALITBANG), untuk lebih jelas terkait data, jenis, cara memperoleh dan peruntukannya dapat dilihat pada tabel 1 .

\section{Metode Analisis Data}

Data yang diperoleh akan dianalisis menggunakan beberapa metode seperti analisis tumpang susun (overlay) peta bidang tanah, peta RBI, dan peta bidang tanah, serta data kejadian HT untuk mengetahui sebaran HT. Untuk penentuan rasio pola sebaran kejadian hak tanggungan menggunakan analisis rerata tetangga terdekat (Average Nearest Neighbor) dan penyajian menggunakan analisis spasial "density feature" pada ArcGIS. Oleh Pujayanti, Susilo, \& Puspitaningrum (2014), analisis tetangga terdekat merupakan analisis untuk mengetahui dan menjelaskan pola sebaran dari titik likasi dengan menggunakan jarak, jumlah titi lokasi, dan luas area. Menurut analisis tetangga terdekat adalah analisis pendekatan keruangan/spasial memfokuskan pada distribusi keruangan dan lokasi fitur pada suatu wilayah sehingga dapat melakukan penataan dan pengelolaan.

Untuk interpetasi dari hasil perhitungan statistik spasial digunakan rasio rerata tetangga terdekat (nearest neighbor ratio-NNR), dimana jika nilai NNR kurang dari satu $(<1)$, menunjukkan pola mengelompok/memusat (clustering), jika nilai NNR lebih besar dari satu $(>1)$ maka tren mengarah ke pola menyebar/tersebar merata/teratur (dispersed), dan nilai NNR = 1 berarti polanya acak (random) (ESRI, 2018), dan diperkuat dengan nilai-z (z-score) dan nilai-p (p-value). Ilustrasi jenis pola sebaran untuk fitur kejadian hak tanggungan dapat dilihat pada gambar 2.

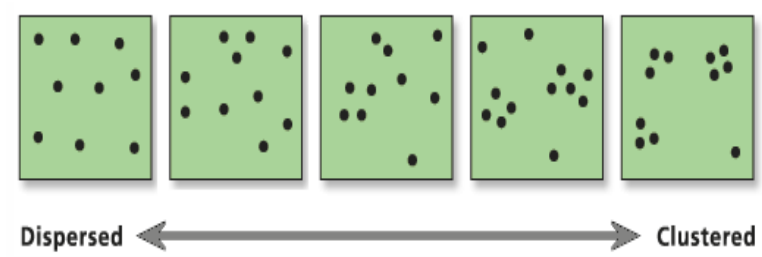

Sumber : ESRI, 2018

Gambar 2. Ilustrasi Tetangga

\section{Terdekat Rata-rata (ESRI, 2018)}

Pola hak tanggungan dengan analisis deskriptif dari data peta sebaran kejadian dan nilai hak tanggungan terkait dengan perkembangan Perkotaan Purwokerto baik dari struktur kotanya. Untuk mengidentifikasi perkembangan Perkotaan Purwokerto digunakan analisis spasial kepadatan titik lokasi pelayanan publik/ kerapatan fitur pelayanan (density points feature) terhadap pusat-pusat pelayanan seperti (perekonomian, pemerintahan, pendidikan, kesehatan, dan trasportasi). Penggunaan tanah pada penelitian ini diklasifikasikan menjadi dua penggunaan tanah terbangun dan non terbangun sesuai dengan (Kivell, 1993).Untuk analisis kontribusi hak tanggungan terhadap perubahan penggunaan tanah di wilayah Perkotaan Purwokerto di hitung menggunakan modifikasi dari rumus pencarian ICOR (incremental capital output ratio), dimana hasil kalkulasi ditemukan persamaan sebagai berikut: $\frac{(B-A) /_{C} \times\left(\sum D\right)}{A / C \times\left(\sum D\right)}$

\section{Dimana}

A : Penggunaan Tanah Tahun awal penelitian B : Penggunaan Tanah Tahun akhir penelitian $\mathrm{C}$ : Luas Wilayah $\Sigma \mathrm{D}$ : Jumlah HT dari tahun awal penelitian sampai tahun akhir penelitian

\section{HASIL DAN PEMBAHASAN \\ Pola Sebaran Hak Tanggungan di Perkotaan \\ Purwokerto}

Hasil analisis spasial dan statistik untuk pola sebaran kejadian HT/hipotek menggunakan analisis statistik spasial (analisis rerata tetangga terdekat/Average Nearest Neighbor) ditemukan jika pola sebarannya kecenderungan mengelompok (clustered) pada lokasilokasi tertentu. Nilai rasio ANN (Average Nearest Neighbor) sebesar 0.572 ditahun 2012 dan semakin mengelompok dengan nilai rasio ANN sebesar 0.625 di tahun 2017. Untuk lebih jelas nilai hasil analisis rerata tetangga terdekat (ANN) dapat dilihat pada gambar 3.

Gambar 2 juga memberi arahan bahwa semakin terakumulasi jumlah kejadian HT/Hipotek disuatu titik/lokasi maka kecenderungan pengelompokan pada lokasi tersebut tiap tahunnya akan menguat, hal tersebut terbukti dengan adanya penurunan nilai rasio tetangga terdekat (semakin kecil nilainya maka akan semakin mengelompok). Berdasarkan kalkulasi jumlah kejadian hak tanggungan dan nilai tanggungan di tiap kelurahan ditemukan pola perambatan kejadian maupun nilai tanggungan dari tahun 2012-2017 sepanjang koridor jalanutara-selatansepertiyangtergambarpadagambar4.

Gambar 4 memberi informasi dimana koridor utara-selatan berdasarkan observasi dilokasi penelitian berdasarkan nilai tanggungan adalah area pusat kegiatan dan pertumbuhan ekonomi yang ke utara merupakan area perniagaan yang menunjang pelayanan 

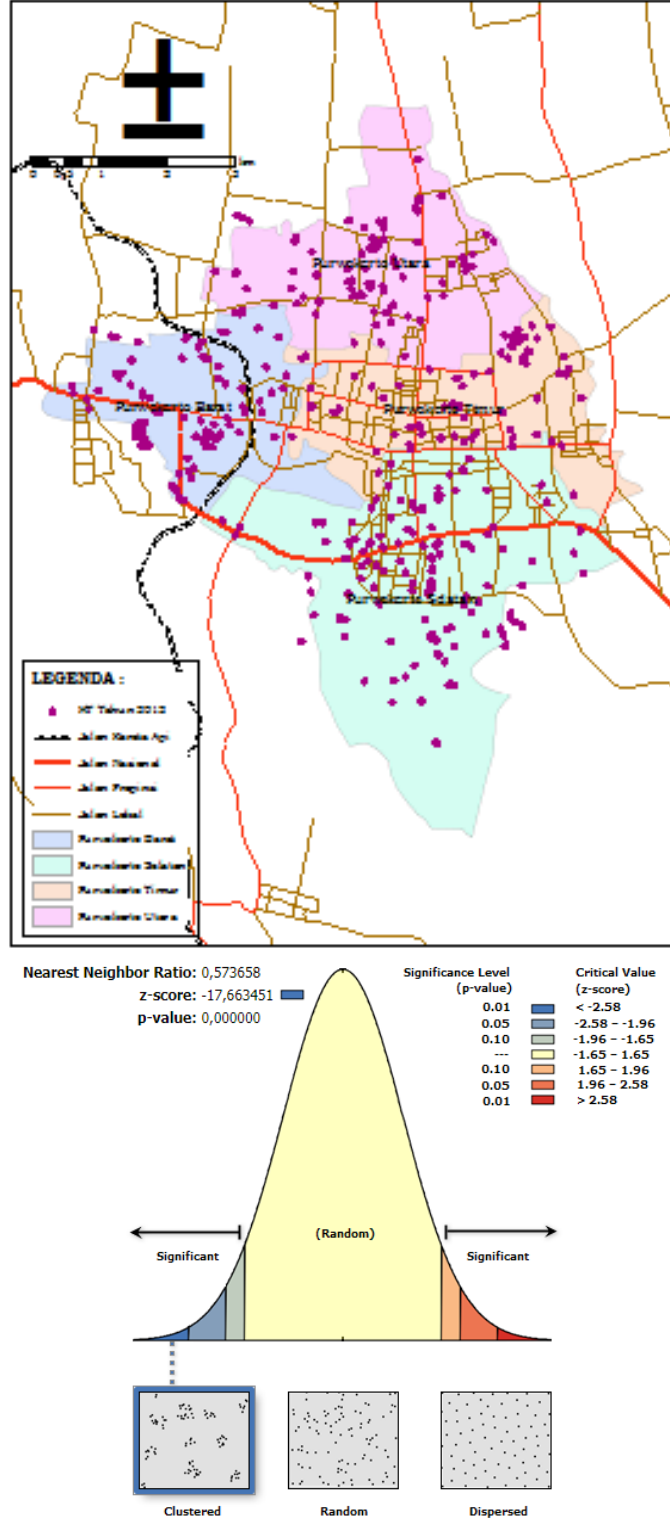

Given the $z-$-score of -17.66 , there is a less than $1 \%$ likelihood that this clustered pattern could be the result of random chance.

Tahun 2012
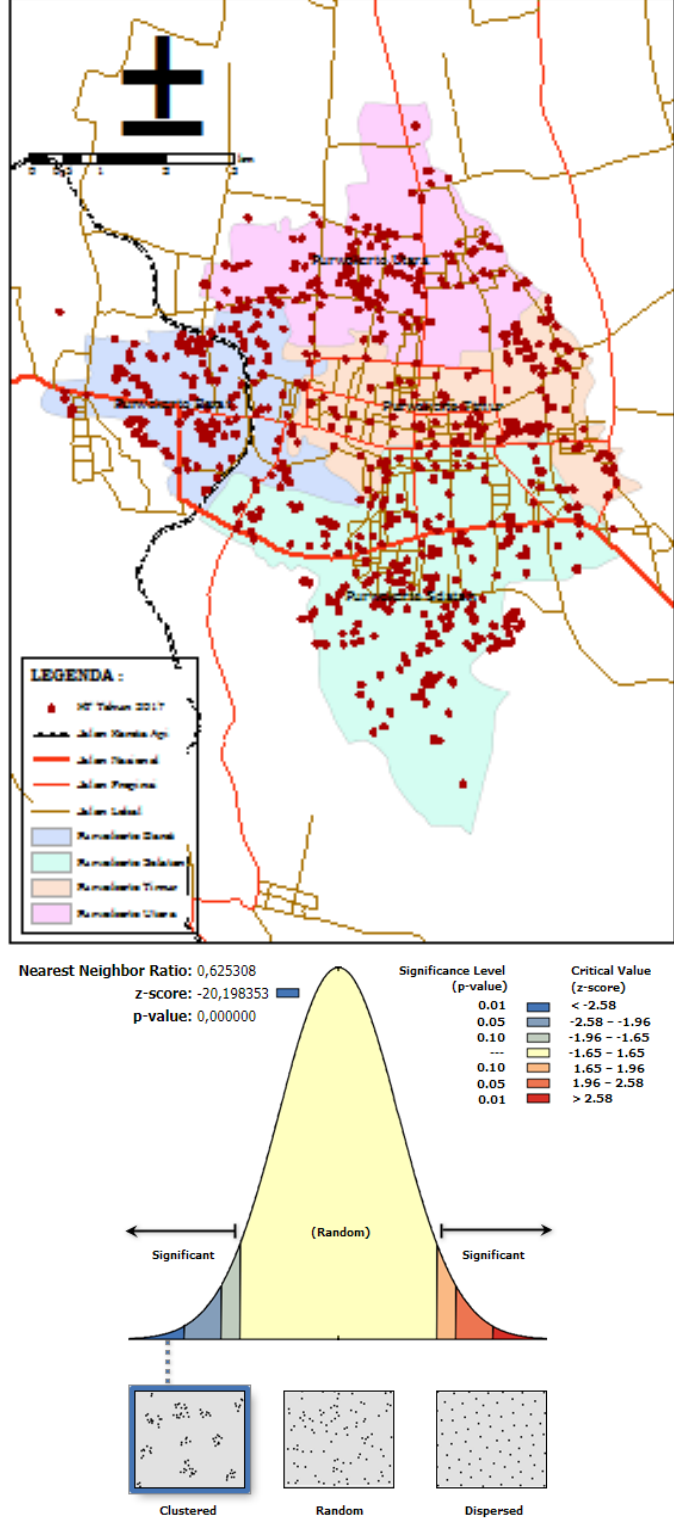

Given the $z$-score of -20.20 , there is a less than $1 \%$ likelihood that this clustered pattern could be the result of random chance.

Tahun 2017

Sumber : Analisis 2018

Gambar 3. Hasil Analisis Average Nearest Neighbor (ANN) Tahun 2012 dan 2017 Perkotaan Purwokerto

pendidikan untuk usaha dan jasa. Lain halnya yang arah selatan merupakan area perdagangan dan pergudangan. Jika berdasarkan banyaknya kejadian hak tanggungan untuk koridor utara ke selatan merupakan arah perkembangan properti baru (khususnya residensial property), dimana hal ini juga terdapat dalam kebijakan penambahan pemukiman baru . Penentuan kebijakan pemukiman baru dikarenakan luas tanah yang belum terbangun di wilayah tersebut masih besar, hal ini dapat dilihat pada rasio luas wilayah terbangun pada tiap kelurahan yang berapa pada koridor tersebut pada tahun 2012 sebagai awal tahun penelitian to (tabel 2).

Tabel 2 dan arah perambatan kejadian HT/ Hipotek (gambar 4) memberikan informasi bahwa area perkembangan baru diutamakan pada lokasi dengan luasan terbangun yang masih kecil rasio luas terbangunnya, hal ini dibuktikan dengan adanya peningkatan yang cukup signifikan untuk perubahan guna tanah pada lokasi-lokasi tersebut (kecuali pada kelurahan yang masuk CBD seperti Purwokerto Lor, Purwokerto Wetan dan Purwokerto Kulon). Untuk Kelurahan Arcawinangun perubahan penggunaan tanahnya cukup tinggi sebesar 23\%, karena lokasi tersebut dekat dengan kampus UNSOED dan UMP serta dekat dengan CBD sehingga perkembangannya cukup cepat karena banyak pelajar yang ingin menuntut ilmu di Purwokerto.

Gambar 5 memberikan gambaran bahwa nilai tanggungan terkonsentrasi dipusat pertumbuhan Perkotaan Purwokerto (tahun 2012), dan pada tahun 


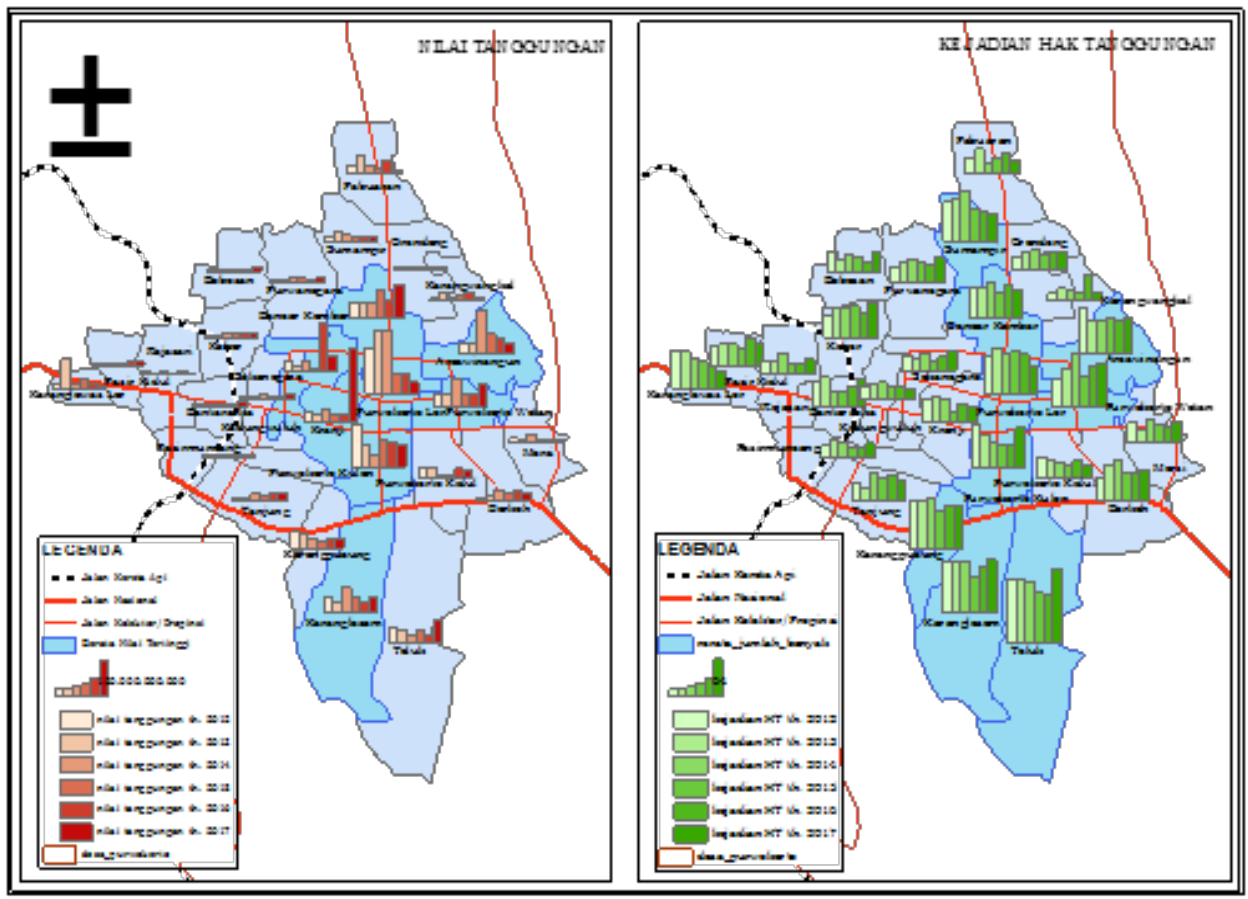

Sumber : Analisis 2018

Gambar 4. Nilai Tanggungan dan Kejadian Hak Tanggungan dalam 6 Tahun di Perkotaan Purwokerto

Tabel 2. Rasio Area Terbangun dan Rasio Perubahan Penggunaan Tanah Tahun 2012-2017

\begin{tabular}{|c|c|c|c|c|c|c|c|}
\hline Kelurahan & $\begin{array}{l}\text { Luas Wilayah } \\
(\mathrm{m} 2)\end{array}$ & $\begin{array}{l}\text { Luas Terba- } \\
\text { ngun (m2) } \\
2012\end{array}$ & $\begin{array}{l}\text { Rasio } \\
\text { Terbangun } \\
\text { (\%) } 2012\end{array}$ & $\begin{array}{l}\text { Rasio } \\
\text { Perubah- } \\
\text { an Guna } \\
\text { Tanah } \\
(\%)\end{array}$ & $\begin{array}{l}\text { Luas Terba- } \\
\text { ngun (m2) } \\
2017\end{array}$ & Agregasi & $\begin{array}{l}\text { Peru- } \\
\text { bahan } \\
2012- \\
2017(\%)\end{array}$ \\
\hline A & B & $\mathrm{C}$ & & $\mathrm{D}$ & $\mathrm{E}$ & $\mathrm{F}$ & \\
\hline Teluk & 4872274,42 & 1107575,99 & $23 \%$ & $64 \%$ & 1729202,07 & 0,56 & $13 \%$ \\
\hline Karangklesem & 3642426,28 & 1151526,29 & $32 \%$ & $74 \%$ & 1562734,34 & 0,36 & $11 \%$ \\
\hline Karangpucung & 1078935,04 & 503666,82 & $47 \%$ & $75 \%$ & 669084,9 & 0,33 & $15 \%$ \\
\hline $\begin{array}{l}\text { Purwokerto } \\
\text { Kulon }\end{array}$ & 1207552,49 & 693376,44 & $57 \%$ & $60 \%$ & 1153999,31 & 0,66 & $38 \%$ \\
\hline $\begin{array}{l}\text { Purwokerto } \\
\text { Wetan }\end{array}$ & 1096747,34 & 654371,61 & $60 \%$ & $74 \%$ & 880435,07 & 0,35 & $21 \%$ \\
\hline $\begin{array}{l}\text { Purwokerto } \\
\text { Lor }\end{array}$ & 1154079,14 & 947045,81 & $82 \%$ & $88 \%$ & 1081839,2 & 0,14 & $12 \%$ \\
\hline Arcawinangun & 1740276,76 & 718887,18 & $41 \%$ & $65 \%$ & 1113492,15 & 0,55 & $23 \%$ \\
\hline Bancarkembar & 1454774,65 & 857266,24 & $59 \%$ & $80 \%$ & 1074703,45 & 0,25 & $15 \%$ \\
\hline Sumampir & 1209304,42 & 548677,73 & $45 \%$ & $78 \%$ & 703023,96 & 0,28 & $13 \%$ \\
\hline
\end{tabular}

Sumber : Analisis 2018

2017 mulai terjadi pemerataan ke arah utara dan selatan yang masih dalam 1 (satu) koridor sistem Pusat Perkotaan Purwokerto. Ada juga konsentrasi nilai tanggungan pada tahun 2017 terjadi pada purwokero barat hal ini dikarenakan lokasi tersebut merupakan pusat UMKM dan perkembangan perumahan baru. Lain halnya pada gambar 6. Informasi yang dapat diperoleh tentang pusat konsentrasi kejadian HT/ hipotek paling besar, pada tahap awal di tahun 2012 terletak di Kecamatan Purwokerto Barat. Lokasi yang mudah dijangkau karena masih satu koridor dengan jalan Jend. Soedirman dan kebijakan arah pertumbuhan perekonomian baru dengan renovasi dan menambah fasilitas pasar, serta pusat UMKM dilokasi tersebut (khususnya Kelurahan Karanglewas Lor, Pasir Kidul, Rejasari dan Bantarsoka). Berjalannya waktu konsentrasi bergeser kearah Utara dan Timur dimana pada area tersebut terdapat Univ. Jend. Soedirman yang dijelaskan dalam Munggiarti and 


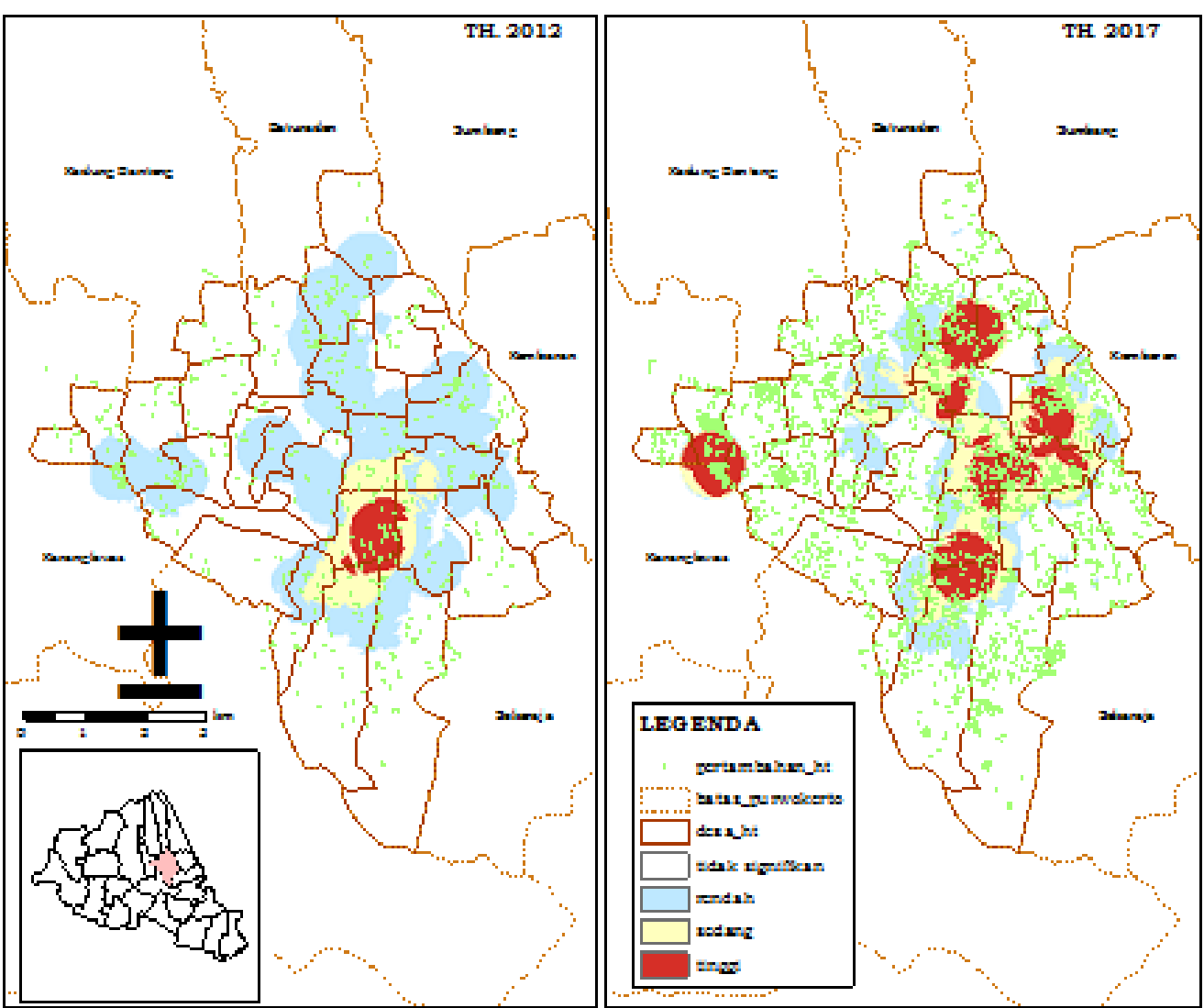

Sumber : Analisis 2018

Gambar 5. Analisis Kepadatan Pola Nilai Hak Tanggungan Perkotaan Purwokerto

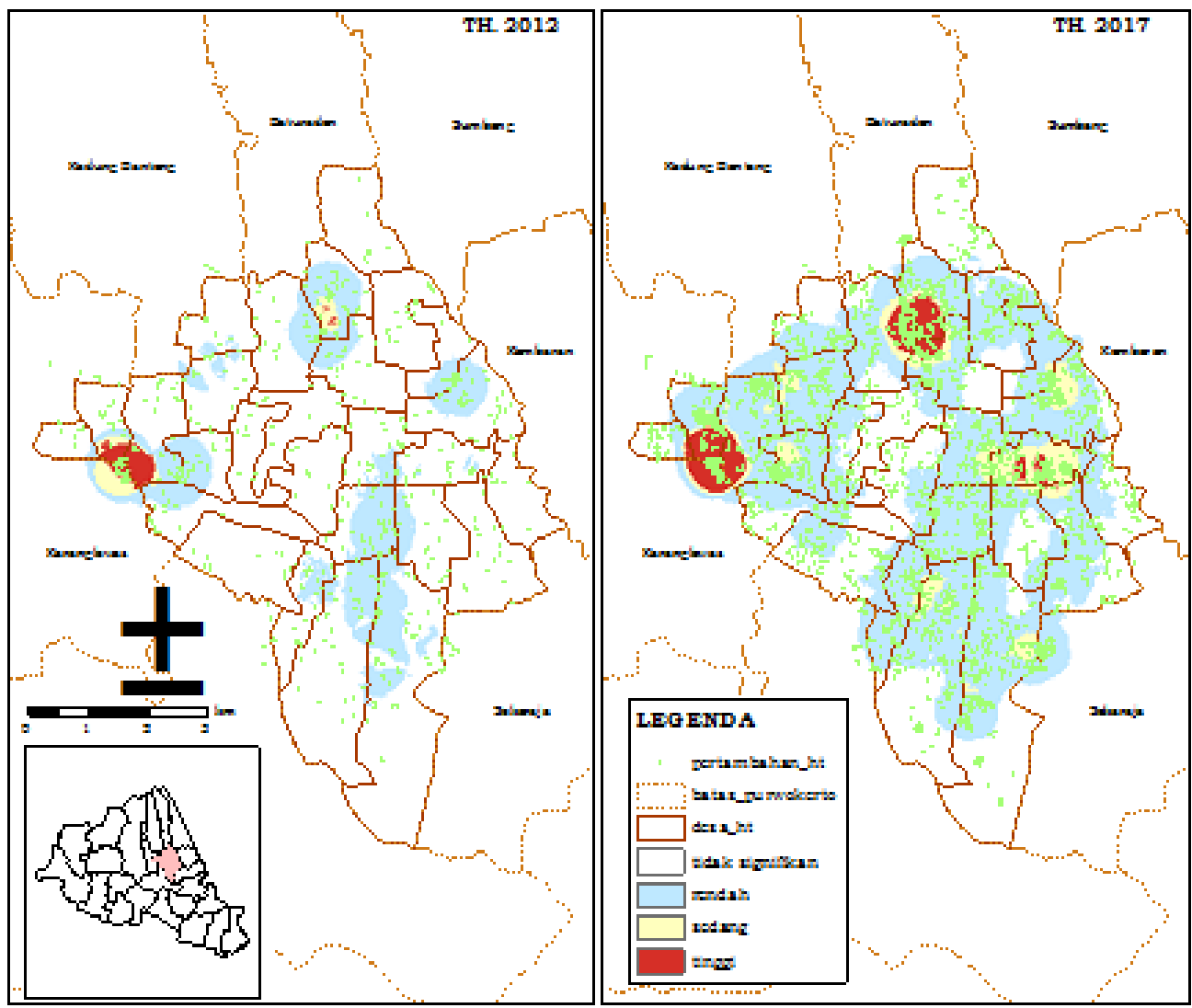

Sumber : Analisis 2018

Gambar 6. Analisis Kepadatan Pola Kejadian Hak Tanggungan Perkotaan Purwokerto 

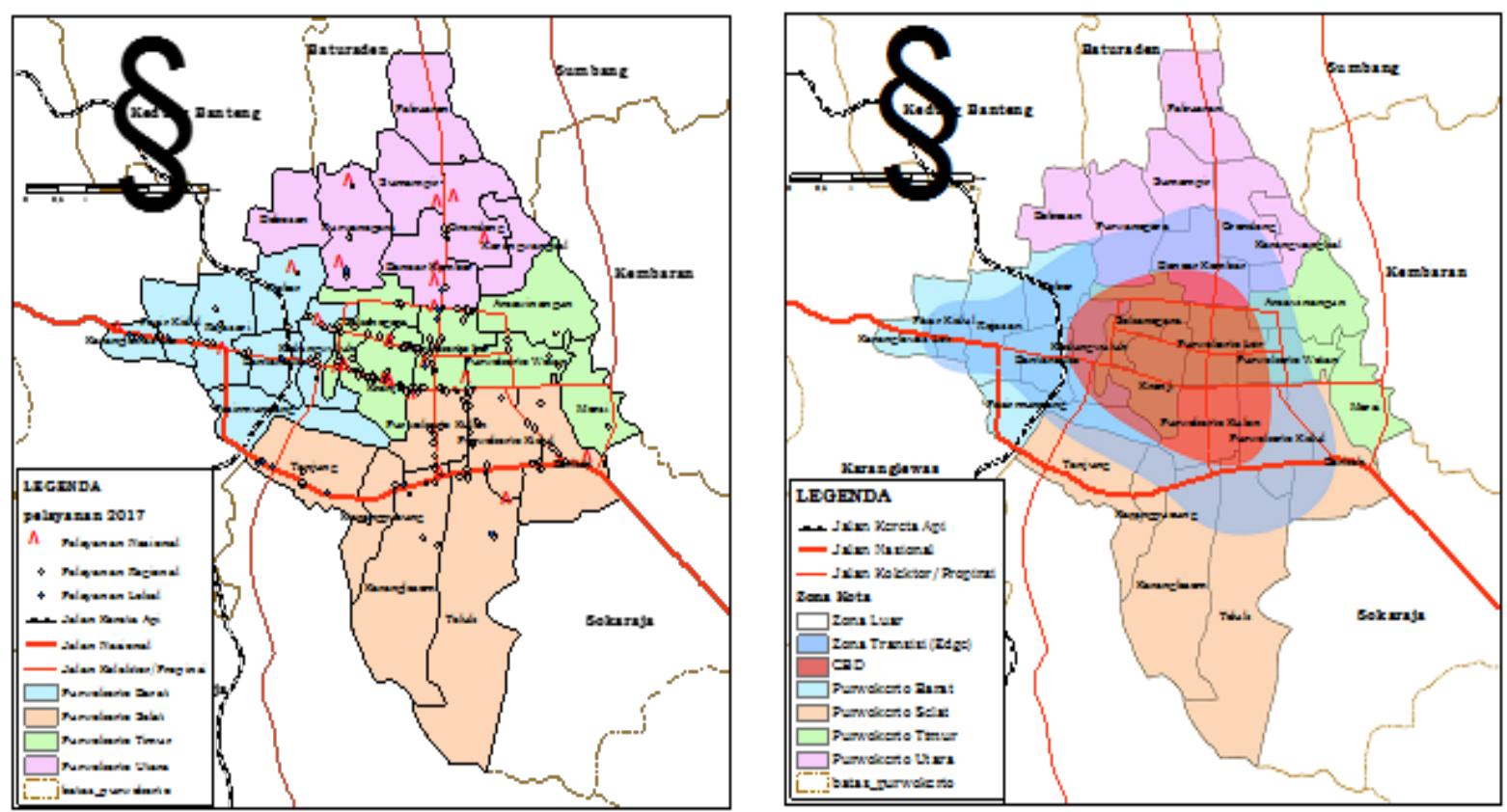

Sumber : Analisis 2018

Gambar 6, Identifikasi Sebaran Lokasi Pelayanan dan Penentuan CBD
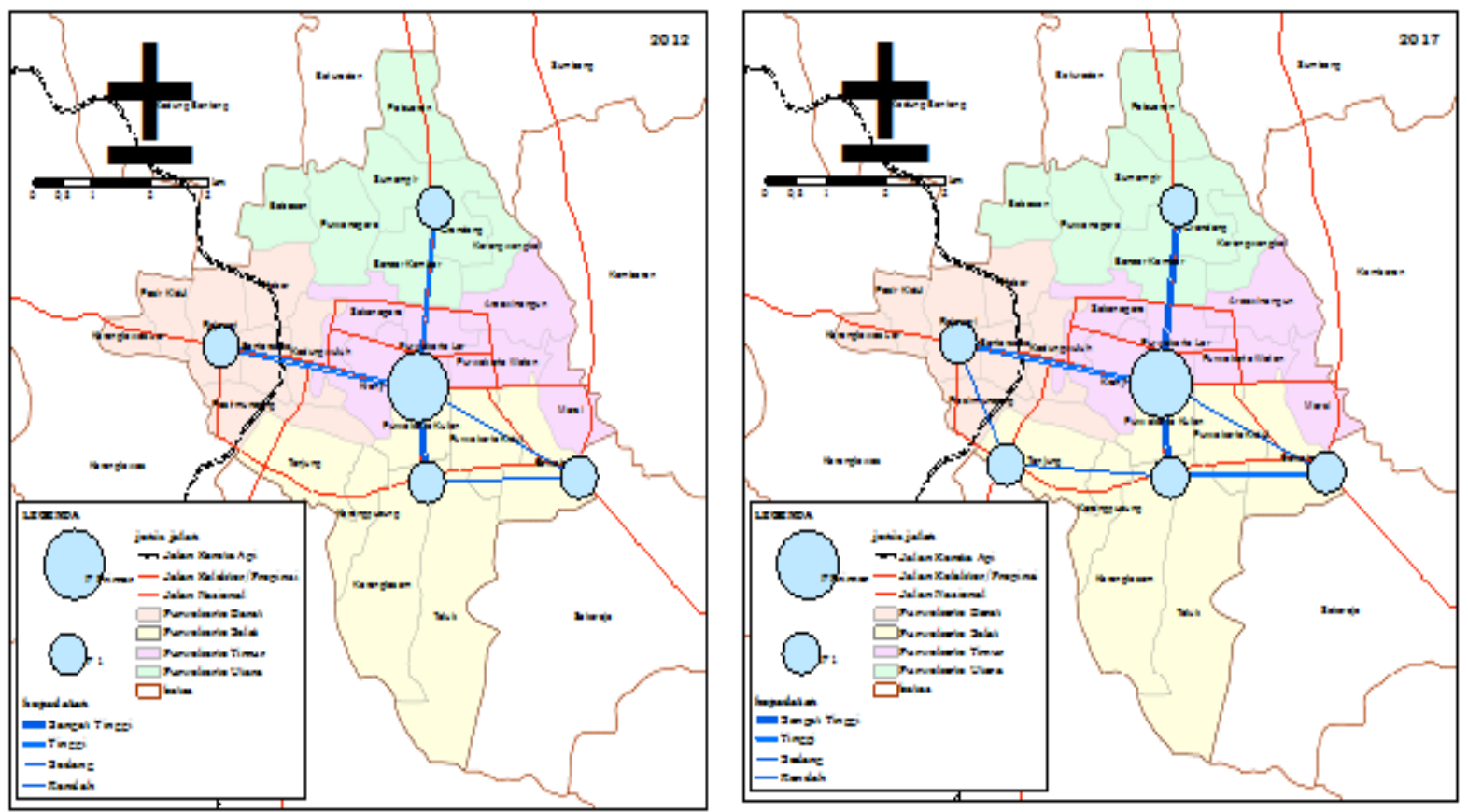

Sumber : Anlisis 2018

Gambar 7. Struktur Ruang Perkotaan Purwokerto Tahun 2012 dan Tahun 2017

Buchori, (2015) ada perubahan guna tanah yang masif pada daerah sekitar lokasi kampus UNSOED. Untuk arah timur adanya pusat pelayanan wilayah pada bidang kesehatan yaitu RSUD Margono dan Fakultas Kedokteran UNSOED serta akses menuju ke luar kota.

\section{Perkembangan Perkotaan Purwokerto Secara Konsentris}

Hasil dari analisis spasial pusat pelayanan publik yang telah diidentifikasi menunjukkan adanya bentuk struktur Perkotaan Purwokerto yang konsentris (terpusat) di CBD sekitar wilayah Kelurahan Kranji,
Kelurahan Purwokerto Lor, dan Kelurahan Purwokerto Kidul, sebagai pusat pelayanan primer (prime services) dari Perkotaan Purwokerto. Hal ini juga sejalan dengan arahan struktur ruang yang diperoleh dari lampiran Perda Kabupaten Banyumas No. 11 Tahun 2011 tentang RTRW Kabupaten Banyumas. Sebaran pusat pelayanan publik dan tempat penting secara visualisasi hasil analisis struktur kota (menggunakan analisis spasial "density feature") dapat dilihat pada gambar 6. Dimana sebaran pelayanan publik hampir tersebar merata di tiap wilayah kecamatan untuk pelayanan pendidikan, kesehatan, dan perdagangan (pasar). Tetapi untuk pusat kegiatan yang 


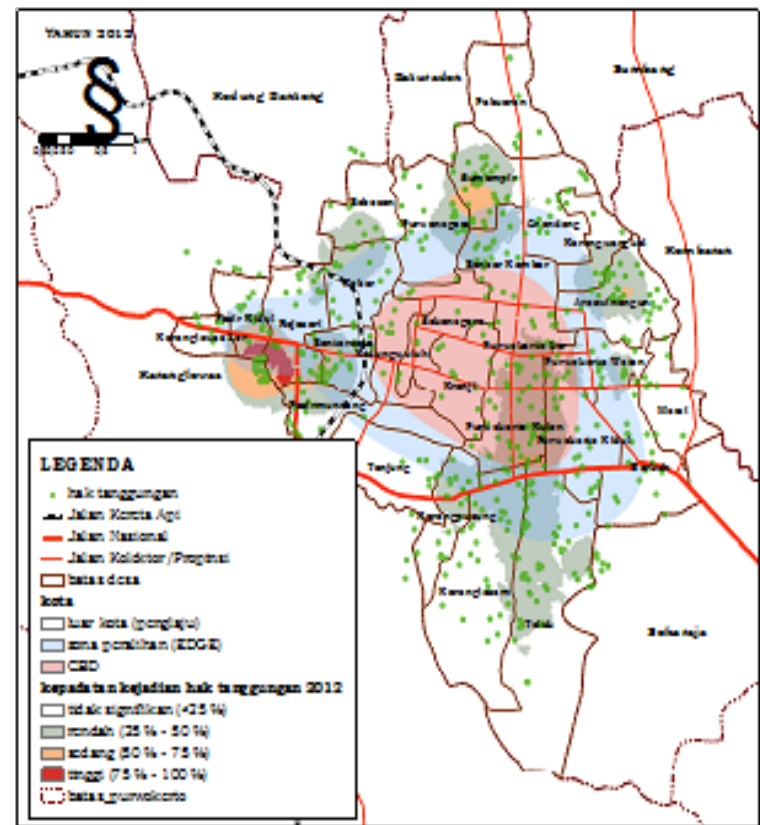

Tahun 2012

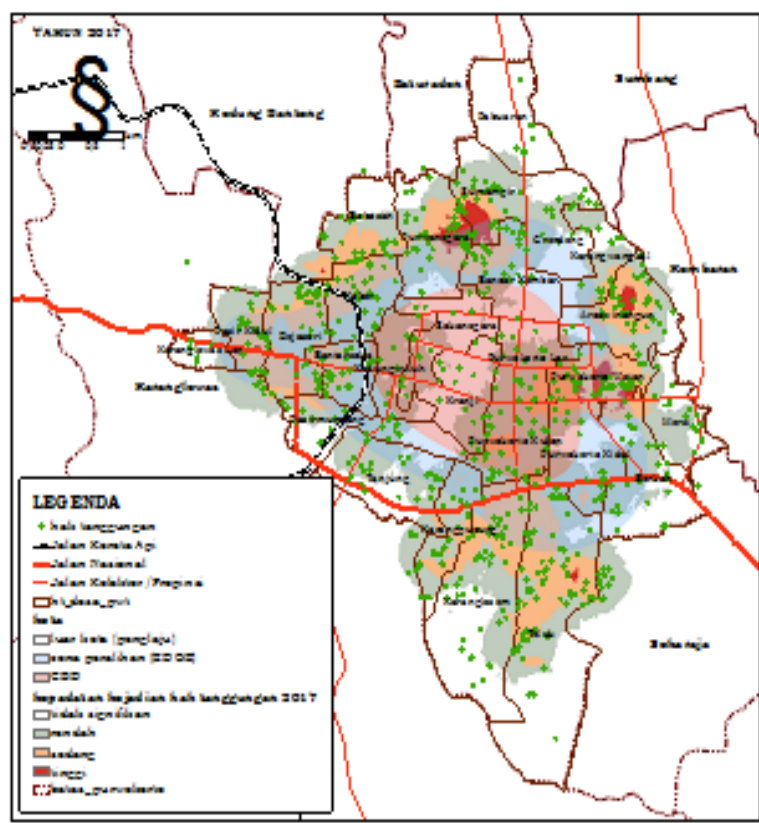

Tahun 2017

Sumber : Analisis 2018

Gambar 8. Perambatan Kejadian Hak Tanggungan di Perkotaan Purwokerto Tahun 2012-2017

Tabel 3. Kontribusi Hak Tanggungan Tiap Kecamatan di Perkotaan Purwokerto

\begin{tabular}{|c|c|c|c|c|c|c|c|}
\hline Kecamatan & $\begin{array}{l}\text { Kejadian HT } \\
\text { 2012-2017 }\end{array}$ & $\begin{array}{l}\text { Luas } \\
\text { Wilayah } \\
(\mathrm{m} 2)\end{array}$ & $\begin{array}{l}\text { Luas terba- } \\
\text { ngun } \\
\text { to (awal) } \\
\text { (m2) }\end{array}$ & $\begin{array}{l}\text { Luas ter- } \\
\text { bangun } \mathrm{t} 1 \\
\text { (akhir) } \\
(\mathrm{m} 2)\end{array}$ & $\begin{array}{l}\text { Perubahan } \\
\text { Guna } \\
\text { Tanah }(\mathrm{m} 2)\end{array}$ & $\begin{array}{l}\text { Rasio } \\
\text { Luas Ter- } \\
\text { bangun } \\
\text { dengan } \\
\text { Kejadian } \\
\text { HT (\%) }\end{array}$ & $\begin{array}{l}\text { Kontribu- } \\
\text { si Keja- } \\
\text { dian HT } \\
\text { terhadap } \\
\text { Perubah- } \\
\text { an Guna } \\
\text { Tanah (\%) }\end{array}$ \\
\hline
\end{tabular}

\begin{tabular}{llllllll}
\hline$(\mathrm{A})$ & $(\mathrm{B})$ & $(\mathrm{C})$ & $(\mathrm{D})$ & $(\mathrm{E})$ & $(\mathrm{F})$ & $(\mathrm{G})$ & $(\mathrm{H})$ \\
$\begin{array}{l}\text { Purwokerto } \\
\text { Utara }\end{array}$ & 823 & 9690388 & 3587797,56 & 5303915,2 & 1716117,64 & $67,64 \%$ & $47,83 \%$ \\
$\begin{array}{l}\text { Purwokerto } \\
\text { Selatan }\end{array}$ & 1114 & 16222894,5 & 5659405,61 & 7972861,17 & 2313455,56 & $70,98 \%$ & $40,88 \%$ \\
$\begin{array}{l}\text { Purwokerto } \\
\text { Barat }\end{array}$ & 742 & 7294544,17 & 3092883,78 & 4420457,66 & 1327573,88 & $69,97 \%$ & $42,92 \%$ \\
$\begin{array}{l}\text { Purwokerto } \\
\text { Timur }\end{array}$ & 723 & 7840739,8 & 4761379,45 & 5864268,54 & 1102889,09 & $81,19 \%$ & $23,16 \%$ \\
\hline
\end{tabular}

Sumber: Analisis 2018

lingkupnya (fungsi) lebih besar/luas banyak berada di wilayah Kecamatan Purwokerto Timur sebagai CBD.

Gambar 6. Memberikan informasi pelayanan cenderung mengelompokan pada lokasi di jalan Jend. Sudirman, pengelompokan berdasarkan analisis kepadatan memberikan klasifikasi lokasi sebagai pusat perekonomian, bisnis dan pelayanan. Perkembangan lokasi/zona peralihan (edge) memiliki kecenderungan lebih besar ke arah barat menuju persimpangan antara jalan nasional (Jln. Veteran) dan jalan propinsi (Jln. Jend. Soedirman). Struktur Perkotaan Purwokerto dari identifikasi lapangan dan analisis pada sebaran lokasi pelayanan menunjukan adanya perubahan dari tahun 2012 sampai tahun 2017. Dimana dari 4 (empat) pusat pelayanan setingkat BWK1 pada tahun 2012 mengalami perubahan menjadi 5 (lima) pusat pelayanan pada tahun 2017 lihat gambar 7. Perkembangan kawasan perkotaan, secara tradisional kota-kota di Indonesia tumbuh dengan pola konsentris kemudian pada skala yang lebih besar seperti wilayah cenderung menyebar.

Hasil identifikasi terhadap perkembangan dan struktur Perkotaan Purwokerto termasuk kota dengan struktur perkotaan konsentris/terpusat (concentric single core) seperti yang dikemukakan oleh Burgess 1925 dalam (Yunus, 2015) dan (Sadyohutomo, 2016), dimana pusat kegiatan sebagai CBD dalam radius $1-1.5 \mathrm{~km}$ yang dikeliling oleh zona peralihan (termasuk didalamnya zona pemukiman) kemudian 
zona terluar dari suatu kota (lihat gambar 6). Zona penglaju yang secara fisik Perkotaan Purwokerto masih didominasi oleh tanah tidak terbangun.

Hubungan antara pola spasial dari hak tanggungan baik kejadian hak tanggungan maupun nilai tanggungannya dengan perkembangan wilayah perkotaan dapat digambarkan dengan analisis overlay peta kepadatan kejadian hak tanggungan dan peta kepadatan nilai tanggungan dengan peta struktur perkotaan. Hasil overlay menunjukkan ada pengelompokan kejadian hak tanggungan dan nilai tanggungan pada lokasi tertentu, dimana pengelompokan kejadian HT/Hipotek diidentifikasi terjadi pada zona peralihan. Hal ini sejalan dengan yang dijelaskan oleh Kim et al., (2016) bahwa dinamika perubahan penggunaan tanah dari tidak terbangun menjadi terbangun (lokasi pemukiman) banyak terjadi pada lokasi dengan karakteristik yang sama dengan zona peralihan (harga tanah lebih rendah, mudah diakses dari pusat kota). Literatur lain menyebutkan bahwa banyaknya investasi atau HT/Hipotek mengelompok pada pusat pertumbuhan (CBD) atau kota yang pertumbuhannyamaju(Rae,2015)danberkorelasipositif terhadap perkembangan wilayah (Asabere et al., 2016).

Beberapa literatur menjelaskan bahwa investasi (dalam hal ini adalah hak tanggungan) memiliki kontribusi terhadap perkembangan fisik wilayah (Glasson \& Marshall, 2007). Studi di Perkotaan Purwokerto menemukan hasil temuan bahwa hak tanggungan juga memiliki kontribusi terhadap perubahan penggguna tanah (non terbangun menjadi terbangun), besar kontribusi tersebut terletak di lokasi Purwokerto Utara (47,88\%). Dimana karakteristik wilayahnya masih banyak area tidak terbangun (tanah kosong dan sawah), harga relatif murah, dan mudah diakses dari pusat kota yang menjadi pemicu kecepatan perubahan guna tanah di wilayah tersebut. Selain itu di Purwokerto Utara juga terdapat Pusat Pelayanan Nasional untuk pendidikan (UNSOED), dimana dalam penelitian yang lain ditunjukkan jika perguruan tinggi (UNSOED) memiliki pengaruh kemasyarakat untuk merubah penggunaan tanahnya (Munggiarti \& Buchori, 2015).

\section{Kejadian Hak Tanggungan Memiliki Pola Mengelompok pada Area Berkembang \\ Setelah mengidentifikasi sebaran kejadian HT/} Hipotek melalui analisis geostatistik dan analisis spasial "density feature" untuk struktur dan pola perkembangan Perkotaan Purwokerto. Informasi yang diperoleh dari tumpang susun peta sebaran kejadian HT/Hipotek dan struktur kota serta pola perkembangan Perkotaan Purwokerto adalah Kejadian HT/Hipotek membentuk pola mengelompok pada wilayah perkembangan baru. Wilayah tersebut berdasarkan observasi dan interpetasi citra memiliki karakteristik masih banyak ruang (tanah) yang belum terbangun dan tersedia akses jalan yang memadai (lihat gambar 5).
Gambar 5 juga memberikan informasi bahwa kejadian HT/Hipotek dan nilai tanggungan juga berpeluang terjadi mengelilingi pusat perkotaan (CBD) tepatnya diantara zona peralihan (edge) dan zona pinggiran/luar kota. Untuk mengetahui perambatan kejadian HT/Hipotek di Perkotaan Purwokerto terhadap struktur perkembangan kota dapat dilihat pada gambar 8. Adanya kejadian hak tanggungan pada tahun 2012 teridentifikasi banyak terjadi di area pinggiran CBD (zona peralihan) untuk area perumahan dengan kepadatan kejadian hak tanggungan yang rendah, sedangkan kejadian hak tanggungan dengan kepadatan tinggi ada di Kecamatan Purwokerto Barat yang menjadi area perniagaan dan pergudangan karena berada di sekitar jalan nasional (Jalan Veteran - Jalan Yos Sudarso). Pada tahun 2017 penjalaran kejadian hak tanggungan merata di zona peralihan mengelilingi CBD (membentuk cincin) dengan kepadatan rendah dan sedang. Untuk kepadatan hak tanggungan yang tinggi ada di beberapa lokasi yaitu di Kelurahan Sumampir, Purwanegara, dan Bancarkembar (Kecamatan Purwokerto Utara) yang merupakan area pusat pelayanan dan pengembangan pendidikan untuk perguruan tinggi baik negeri maupun swasta. Kepadatan haktanggunganyang tinggiberikutnya ada di Kecamatan Purwokerto Timur sebagai pusat pertumbuhan yaitu di Kelurahan Arcawinangun yang merupakan area perumahan dan dekat dengan kampus UNSOED dan UMP. Sedangkan di Kelurahan Purwokerto Wetan yang menjadi pusat kegiatan perniagaan yakni Pasar Wage (pasar terbesar di Purwokerto) yang menjadi pusat perdagangan dan melayani daerah kabupaten sekitarnya serta berada di jalan Jendral Sudirman sehingga aksesnya mudah dijangkau.

Data yang diperoleh dari analisis perubahan guna tanah dalam kurun waktu 6 (enam) tahun dan jumlah kejadian HT/Hipotek (tabel 3) dapat dihitung kontribusi kejadian HT/Hipotek terhadap perubahan penggunaan tanahnya terkait struktur ruang perkotaannya. Tabel 3 juga memberikan informasi tentang besar kecilnya rasio luas terbangun dengan adanya kejadian HT/Hipotek. Adanya kejadian hak tanggungan ikut serta dalam kegiatan pembangunan dan perkembangan spasial perkotaan dengan bertambahnya area terbangun. Dana yang diperoleh dari hak tanggungan banyak dipergunakan untuk membangun perumahan/permukiman, dari tanah non terbangun (tanah kosong) menjadi tanah terbangun, sehingga perkembangan Perkotaan Purwokerto meningkat. Sesuai dengan pendapat Liu \& Zhou, (2005), bahwa perkembangan fisik perkotaan dapat diidentifikasi dari luasan area terbangun.

Hasil perhitungan pada tabel. 3 menjelaskan bahwa kontribusi kejadian hak tanggungan (HT) terhadap perubahan guna tanah di Perkotaan Purwokerto tidak terlalu besar dengan rerata kontribusi sebesar 38,70\%. Wilayah Kecamatan Purwokerto Timur secagai CBD hanya $23,16 \%$ hal ini berarti banyaknya kejadian hak 
tanggungan disana yang digunakan untuk mengubah penggunaan tanah hanya 23,26\% sisanya digunakan untuk kegiatan investasi lainnya. Untuk kontribusi HT tertinggi terjadi di Kecamatan Purwokerto Utara yang mencapai $47,83 \%$, hal ini berarti sebanyak 47,83 \% peminjam memiliki kecenderungan untuk mengubah penggunaan tanahnya dari tanah non terbangun (tanah kosong) menjadi tanah terbangun.

\section{Pembahasan Keterkaitan Kejadian Hak Tanggungan Terhadap Pola Perkembangan Perkotaan}

Temuan dari penelitian ini memberikan gambaran tentang bagaimana hubungan hak tanggungan sebagai investasi privat ikut mempengaruhi struktur perkotaan. Pertama, nilai tanggungan yang besar berada pada lokasi CBD hal ini didukung oleh hasil penelitian Rae, (2015) yang menjelaskan jika pinjaman (hipotek) banyak terjadi dan tersalurkan pada lokasi pusat pertumbuhan kota (CBD). Namun dari jumlah kejadian hipotek yang rendah ada diluar CBD. Hal ini juga terjadi di Perkotaan Purwokerto, dimana terjadi kepadatan yang tinggi terhadap nilai tanggungan di lokasi sekitar pusat perkotaan (CBD). Kedua, kondisi kepadatan yang tinggi di wilayah sekitar pusat kota memberikan gambaran adanya perkembangan pada lokasi tersebut, hal ini ditandai dengan adanya beberapa pusat kegiatan baru yang mulai muncul diwilayah tersebut seperti perumahan baru, peningkatan jalan, dan meningkatnya volume kegiatan perekonomian di pasar. Kondisi ini seperti yang dijelaskan Glasson \& Marshall, (2007) dimana perkembangan wilayah ditandai dengan meningkatnya sumber daya yang dimiliki oleh suatu wilayah, peningkatan aktivitas pasar, dan kondisi perekonomian yang semakin kuat. Kontribusi kejadian Hak Tanggungan terhadap perkembangan perkotaan dapat diketahui juga dengan adanay perubahan guna tanah, dimana dari hasil analisis kontribusi juga diketahui bahwa lokasi-lokasi dengan kontribusi besar merupakan lokasi dengan kepadatan kejadian hak tanggungan tinggi pula (sekitar Purwokerto Utara dan Purwokerto Selatan).

\section{KESIMPULAN}

Hak tanggungan/hipotek sebagai investasi privat/swasta dari jumlah kejadiannya di Perkotaan Purwokerto membentuk pola mengelompok (clustered) di area berkembang terutama lokasi perumahan baru. Untuk pola HT/Hipotek berdasarkan nilai tanggungan yang tinggi banyak terjadi di pusat kegiatan kota (CBD). Untuk struktur kota dan perambatan perkembangan Perkotaan Purwokerto secara fisik/spasial cenderung berbentuk konsentris dengan pola perambatan/penjalaran kotanya linier sepanjang koridor jalur utama Jalan Jenderal Sudirman. Perambatannya ke arah utara pusat pelayanan pendidikan, timur pusat kegiatan perekonomian, sedangkan barat dan selatan area perkembangan baru, dimana pola perkembangan Perkotaan Purwokerto sejalan dengan pola kejadian hak tanggungan dan nilai tanggungan. Terakhir, terkait dengan kontribusi kejadian hak tanggunan terhadap perkembangan fisik/ spasial wilayah perkotaan (dilihat dari guna tanahnya) memiliki nilai rerata sebesar 38, 70\%, dengan kontribusi terbesar di Kecamatan Purwokerto Utara (47,88\%) dan terendah di Kecamatan Purwokerto Timur (28,16\%).

\section{ACKNOWLEDGMENTS}

Terima kasih kepada Kementerian Agraria dan Tata Ruang /BPN Provinsi Jawa Tengah dan Kantor Pertanahan Kabupaten Banyumas yang telah memberikan data dan informasi Hak Tanggungan Perkotaan Purwokerto. Kepada Alasdair Rae, Paul K. Asabere Carl B. McGowan Jr. Sang Mook Lee atas penelitiannya yang telah memberikan inspirasi dan referensi untuk melakukan penelitian ini.

\section{DAFTAR PUSTAKA}

Adisasmita, R. (2013). Teori-Teori Pembangunan Ekonomi Pertumbuhan Ekonomi dan Pertumbuhan Wilayah (1st ed.). Yogyakarta: Graha Ilmu.

Aron, J., \& Muellbauer, J. (2016). “ Modelling and forecasting mortgage delinquency and foreclosure in the UK ". Journal of Urban Economics, 94, 32-53. http://doi.org/10.1016/j.jue.2016.03.005 Asabere, P. K., McGowan Jr., C. B., \& Lee, S. M. (2016). A Study Into the Links Between Mortgage Financing and Economic Development in Africa. International Journal of Housing Markets and Analysis, 9(1), 2-19. http://doi. org/http://dx.doi.org/10.1108/IJHMA-05-2014-0014

Beckmann, M. J. (1969). On the Distribution and Residential. Journal of Economic Theory, 1, 60-67.

Beukes, C. J. (2000). Land and labour: The value of assets. Meditari Accountancy Research, 8(1), 1-13. http://doi.org/10.1108/10222529200000001

Böventer, E. Von. (1975). Regional Growth Theory http://doi.org/10.1080/00420987520080011

Chen, H., Wang, X., \& Singh, B. (2017). Can Private Domestic Investment Lead Chinese Technological Progress? Economic Modelling, (November), 1-8. http://doi.org/10.1016/j.econmod.2017.11.002

Dobrescu, E. M., \& Dobre, E. M. (2014). Theories Regarding the Role of the Growth Poles in the Economic Integration. Procedia Economics and Finance, 8(14), 262-267. http://doi.org/10.1016/S2212-5671(14)00089-6

Domar, E. (1957). Essays in The Theory of Economics Growth (1st ed.). New York: Oxford University Press.

ESRI. (2018). What is a $\mathrm{z}$-score? What is a p-value? Retrieved February 16, 2018, from http://desktop. arcgis.com/en/arcmap/10.3/tools/spatial-statisticstoolbox/what-is-a-z-score-what-is-a-p-value.htm

Felice,G.(2016).EuropeanJournalofPoliticalEconomySizeand composition of public investment, sectoral composition and growth. European Journal of Political Economy, 44, 136-158. http://doi.org/10.1016/j.ejpoleco.2016.07.001

Frick, S. A., \& Rodríguez-Pose, A. (2018). Change in Urban Concentration and Economic Growth. World Development, 105, 156-170. http:// doi.org/ $10.1016 /$ j.worlddev.2017.12.034

Glasson, J., \& Marshall, T. (2007). Regional Planning (1st ed.). New York: Taylor \& Francis. Harrod, R. (1963). The British Economic (1st ed.). New York: McGraw Hill. 
Nesty Vie Laily, dkk/Majalah Geografi Indonesia, Vol. 33 No.1, Maret 2019 : 57 - 67

Hermit, H. (2009). Teknik Penaksiran Harga Tanah Perkotaan Teori dan Praktek Penilaian Tanah (1st ed.). Bandung: Mandar Maju. Jiang, G., Ma, W., Dingyang, Z., Qinglei, Z., \& Ruijuan, Z. (2017). Agglomeration or dispersion? Industrial land-use pattern and its impacts in rural areas from China's township and village enterprises perspective. Journal of Cleaner Production, 159, 207-219. http://doi.org/10.1016/j.jclepro.2017.04.152

Kim, J.-H., Li, W., Newman, G., Kil, S.-H., \& Park, S. Y. (2016). The influence of urban landscape spatial patterns on single-family housing prices. Environment and Planning B: Planning and Design, 45(1), 26-43. http://doi.org/10.1177/0265813516663932

Kim, J., \& Wang, Y. (2018). Journal of Economic Dynamics \& Control Macroeconomic and distributional effects of mortgage guarantee programs for the poor. Journal of Economic Dynamics and Control, 87, 124-151. http://doi.org/10.1016/j.jedc.2017.12.005

Kivell, P. (1993). Land and The City Patterns and Processes of Urban Change (1st ed.). Canada: Taylor \& Francis.

Liu, H., \& Zhou, Q. (2005). Developing Urban Growth Predictions from Spatial Indicators Based on Multitemporal Images. Computers, Environment and Urban Systems, 29(5 SPEC. ISS.), 580-594. http:// doi.org/10.1016/j.compenvurbsys.2005.01.004

Munggiarti, A., \& Buchori, I. (2015). Pengaruh Keberadaan PerguruanTinggiTerhadapPerubahanMorfologiKawasan Sekitarnya. Geomatics and Planning, 2(1), 51-68. http:// doi.org/https://doi.org/10.14710/geoplanning.2.1.51-68

Nasucha, C. (1995). Politik Ekonomi Pertanahan dan Struktur Perpajakan Atas Tanah (1st ed.). Jakarta: Megapoin.

Nwamara, C. C., \& Aronu, C. O. (2014). The Impact of Economic Development on Land Mortgage Financing in Nigeria. Open Science Journal of Mathematics and Application, 2(3), 26-32. Retrieved from http://www.openscienceonline.com/journal/osjma

OECD. (2011). National Accounts at a Glance 2011 (1st ed.). Paris: OECD Publishing. http://doi.org/ http://dx.doi.org/10.1787/na_glance-2011-en

Pemerintah Kabupaten Banyumas. Peraturan Daerah Kabupaten Banyumas Nomor 10 Tahun 2011 Tentang Rencana Tata Ruang Wilayah Kabupaten Banyumas Tahun 2011-2031 (2011). Purwokerto.

Pemerintah Republik Indonesia. Undang-Undang Republik Indonesia Nomor 4 Tahun 1996 Tentang Hak Tanggungan Atas Tanah Beserta Benda-Benda yang Berkaitan dengan Tanah (1996). Jakarta.

Peng, C., Song, M., \& Han, F. (2017). Urban Economic Structure, Technological Externalities, and Intensive Land Use in China. Journal of Cleaner Production, 152, 47-62. http://doi.org/10.1016/j.jclepro.2017.03.020

Pujayanti, J. A. D., Susilo, B., \& Puspitaningrum,
D. (2014). Sistem Informasi Geografis Untuk Analisis Persebaran Pelayanan Kesehatan di Kota Bengkulu. Jurnal Rekursif, 2(2), 99-111. Retrieved from http://download.portalgaruda.org/article. php article $=299334 \&$ val $=7008 \&$ title $=$ Sistem Informasi Geografis Untuk Analisis Persebaran Pelayanan Kesehatan di Kota Bengkulu Putri, T. D., Gunarto, T., \& Saimul. (2013). Analisis Pengaruh Pendapatan Asli Daerah dan Pengeluaran Pemerintah Terhadap Perkembangan Ekonomi Provinsi Lampung Tahun 2000-2013. Jurnal Ekonomi, 1-25. Retrieved from http://feb.unila.ac.id/mie/ wp-content/uploads/2015/08/“Analisis-PengaruhPendapatan-Asli-Daerah-Dan-PengeluaranPemerintah-Terhadap-Perkembangan-EkonomiProvinsi-Lampung-Tahun-2000-2013-Tria.pdf\%0A

Rae, A. (2015). The Illusion of Transparency: The Geography of Mortgage Lending in Great Britain. Journal of European Real Estate Research, 8(2), 172195. http://doi.org/10.1108/JERER-08-2014-0030 Sadyohutomo, M. (2016). Tata Guna Tanah dan Penyerasian Tata Ruang (1st ed.). Yogyakarta: Pustaka Pelajar. Shi, Y., Guo, S., \& Sun, P. (2017). Journal of Asian Economics The role of infrastructure in China's $s$ regional economic growth. Journal of Asian Economics, 49, 26-41. http://doi.org/10.1016/j.asieco.2017.02.004 Sutarno, \& Kuncoro, M. (2003). Dan Ketimpangan Antar Kecamatan Di Kabupaten Banyumas, 1993-2000. Jurnal Ekonomi Pembangunan, 8(2), 97-110. Retrieved from http://www.jurnal.uii.ac.id/JEP/article/view/630/560

Syahyuti, S. (2011). Delandreformisasi Sebagai Gejala Anti Landreform di Indonesia: Karakter, Penyebab dan Upaya untuk Pengendaliannya. Forum Penelitian Agro Ekonomi, 29(2), 67-81. Retrieved from http://ejurnal. litbang.pertanian.go.id/index.php/fae/article/view/3892

Udoka, C. O., \& Kpataene, O. M. (2017). Mortgage Financing and Housing Development in Nigeria. International Journal of Research-Granthaalayah, 5(5), 57-67. http://doi.org/https://doi.org/10.5281/zenodo.583909

Wang, W., Zhang, X., Wu, Y., Zhou, L., \& Skitmore, M. (2017). Development Priority Zoning in China and its Impact on Urban Growth Management Strategy. Cities, 62, 1-9. http://doi.org/10.1016/j.cities.2016.11.009

Whipple, R. T.M. (1995). Relationship between land values and uses in Sydney's central area. Journal of Property Finance, 06(4), 63. http://doi.org/10.1108/09588689510731929

Yunus, H. S. (2015). Struktur Tata Ruang Kota (10th ed.). Yogyakarta: Pustaka Pelajar. 